\title{
The Credit Cycle and the Business Cycle in the Economy of Turkey
}

\author{
Şehnaz Bakır Yiğitbaş \\ Çanakkale Onsekiz Mart University, Çanakkale, Turkey
}

\begin{abstract}
This study examines econometric relationships between bank lending and the business cycle in Turkey. Firstly, the cyclical components of the real GDP and real bank loans were determined using time series. A cointegration analysis and a vector error-correction model with quarterly data were used for period of 1987:01-2013:03. The results of cointegration analysis indicate that there is a single stable long-run equilibrium relationship between real bank loans and macroeconomic variables. The response of bank loans to GDP shocks is positive. Bank loans have pro-cyclical character in Turkey.

Keywords: business cycle, credit cycle, Turkish economy
\end{abstract}

\section{Introduction}

The global crisis has highlighted the connection between credit conditions and economic performance. Economists have struggled with the question of whether banks change their lending standards systematically over the business cycle. Bernanke and Gertler (1989) argued that bank lending is not only pro-cyclical, but that availability of bank loans may also increase the magnitude of business cycles. Gambetti and Musso (2012) argued that the impact of loan supply shocks is particularly important during slowdowns in economic activity.

Banks are important institutions which finance household and business spending in Turkey. The share of bank loans in external financing of the private sector is around 82\% (CBRT, 2012). In this respect, testing the relationship between the business cycle and bank lending is important. The purpose of this study is to analyze the relationship between bank loans and business cycles in terms of Turkey's economy. The rest of this study is structured as follows: Section II explores the cyclical component of the real GDP and real banking loans using time series in Turkey. Thus whether bank loans were procyclical, countercyclical, or acyclical is determined. Section III provides the data, econometric approach, and empirical results. Finally, Section IV presents the conclusions of this study.

\section{The Credit Cycle and the Business Cycle in the Economy of Turkey}

There are a large number of statistical methods that are used to separate the cyclical component of a time series from raw data. The Hodrick-Prescott (HP) filter is the most widely used technique. It is used to obtain a

Şehnaz Bakır Yiğitbaş, Ph.D., lecturer, Department of Finance-Banking and Insurance, Çanakkale Onsekiz Mart University, Çanakkale, Turkey.

Correspondence concerning this article should be addressed to Şehnaz Bakır Yiğitbaş, Department of Finance-Banking and Insurance, Çanakkale Onsekiz Mart University, 17860 Ayvacık, Çanakkale, Turkey. 
smoothed-curve representation of a time series, one that is more sensitive to long-term than to short-term fluctuations. The adjustment of the sensitivity of the trend to short-term fluctuations is achieved by modifying a multiplier $\lambda$. For quarterly data Hodrick and Prescott (1997) proposed a value of $q=1 / 1600$.

Rand and Tarp (2002) observed that business cycles in developing countries are significantly shorter in duration compared to cycles in developed countries, making $\lambda=1,600$ inappropriate for developing countries. Alp, Başkaya, Kilinç, and Yüksel (2011) estimated the optimal smoothing for Hodrick-Prescott filter for Turkey using 1987-2007 quarterly real GDP data, and found that for the shorter business cycle length in Turkey the optimal $\lambda$ was 98 and 17. Using the finding on the average length of the business cycle for Turkey, the HP-filter smoothing parameter is estimated for Turkey as 98 with the methodology proposed by Pedersen (2001). Figure 1 shows the turning points in Turkish real GDP series from 1987 to 2013.

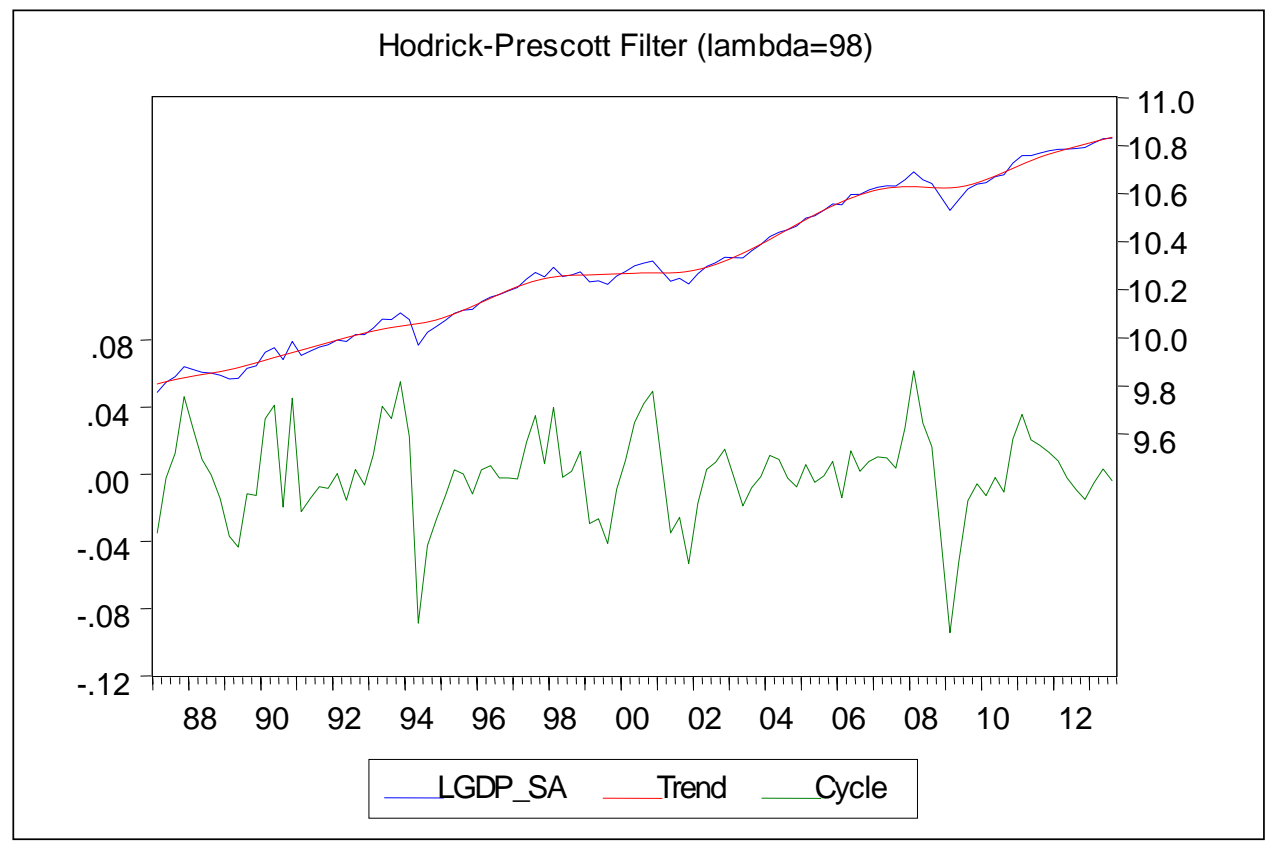

Figure 1. Turning points in Turkish real GDP (1987Q1-2013Q3). Source: Central Bank of Republic of Turkey (CBRT). Real GDP data is seasonally adjusted with Census X12 after taking natural logarithms.

Figure 2 shows business cycles in Turkey for period of 1987:01-2013:03. Real GDP narrowed substantially during 1994, 2000-2001, and 2008-2009 crises. The first trough point is observed in the beginning of 1989, which is followed by the one in 1994:02, which reflects repercussions of the 1994 economic crisis. The third trough appears in period of 1998-1999 reflecting the effects of Russian crisis. The trough point observed in 2001 coincides with the Turkish banking crisis. The last trough point is observed in the period of 2008-2009 reflecting the effects of the global economic crisis. In the same periods, bank loans dropped to the lowest level (Figure 3).

To capture financial fluctuations and real fluctuations, loan growth rate and GDP growth rate are used (Egert \& Sutherland, 2012). Figures 4, 5, 6, 7, and 8 show the relationship between loan growth and GDP growth in Turkey. In this study, five different sub-periods are determined for the period of 1987-2013. These periods are as follows: 1987:01-1994:01, 1994:02-1997:04, 1998:01-2001:04, 2002:01-2006:04, and 2007:01-2013:03. Table 1 shows the descriptive statistics of real GDP growth rate and real loan growth rate for 
each period. The real credit growth and real gross domestic product coincide in Turkey. Therefore, it is possible to say that the bank loans in Turkey have pro-cyclical character.

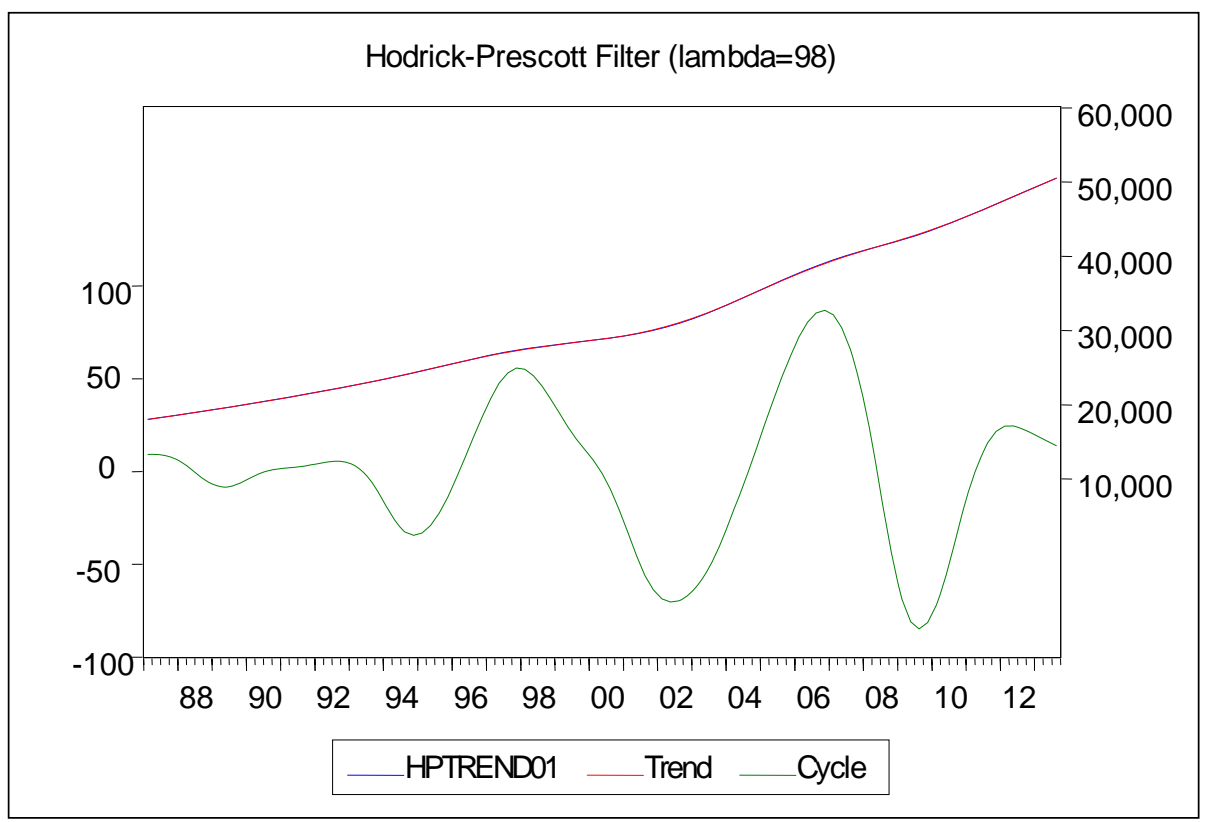

Figure 2. Business cycles in Turkey (1987Q1-2013Q3). Source: Central Bank of Republic of Turkey (CBRT). Real GDP data is seasonally adjusted with Census X12 after taking natural logarithms.

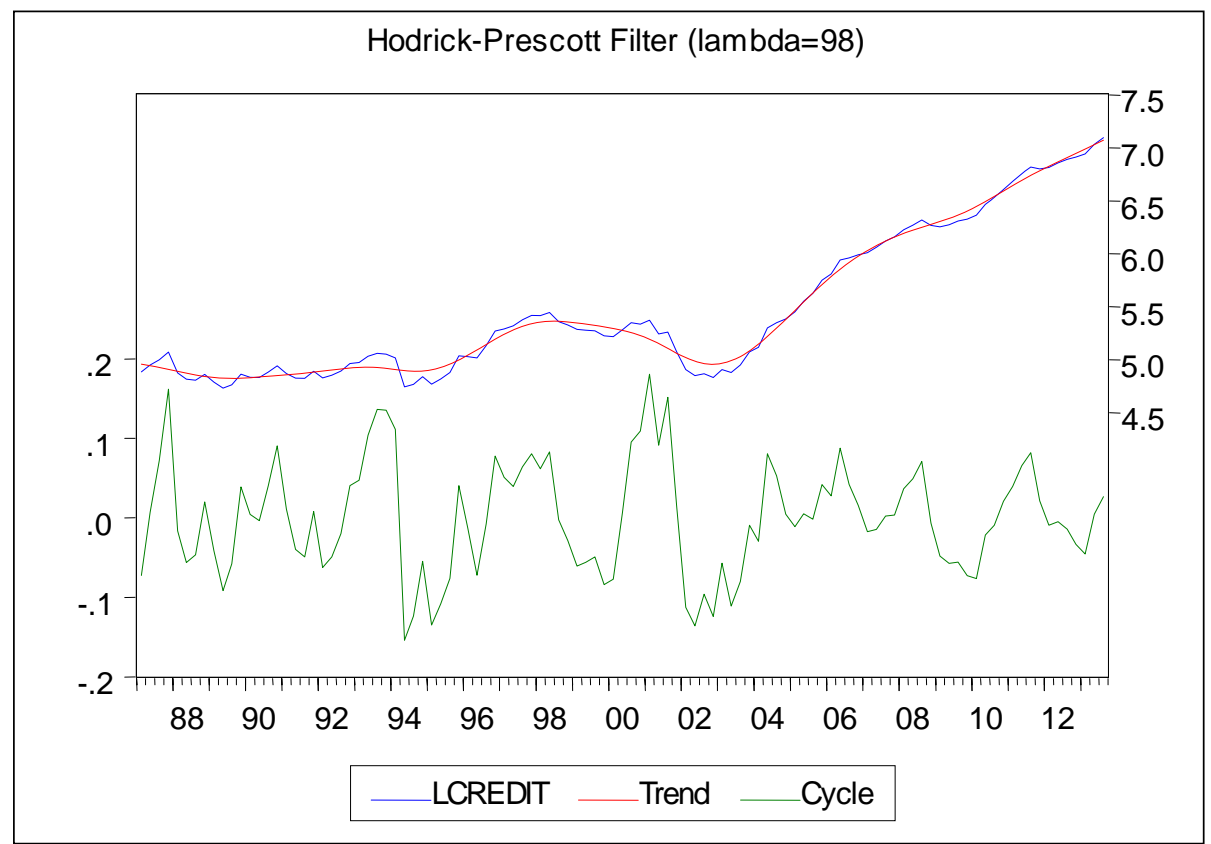

Figure 3. Turning points in Turkish real bank loans (1987Q1-2013Q3). Source: Central Bank of Republic of Turkey (CBRT). Loan data were converted to real terms using $1987=100$ index. 


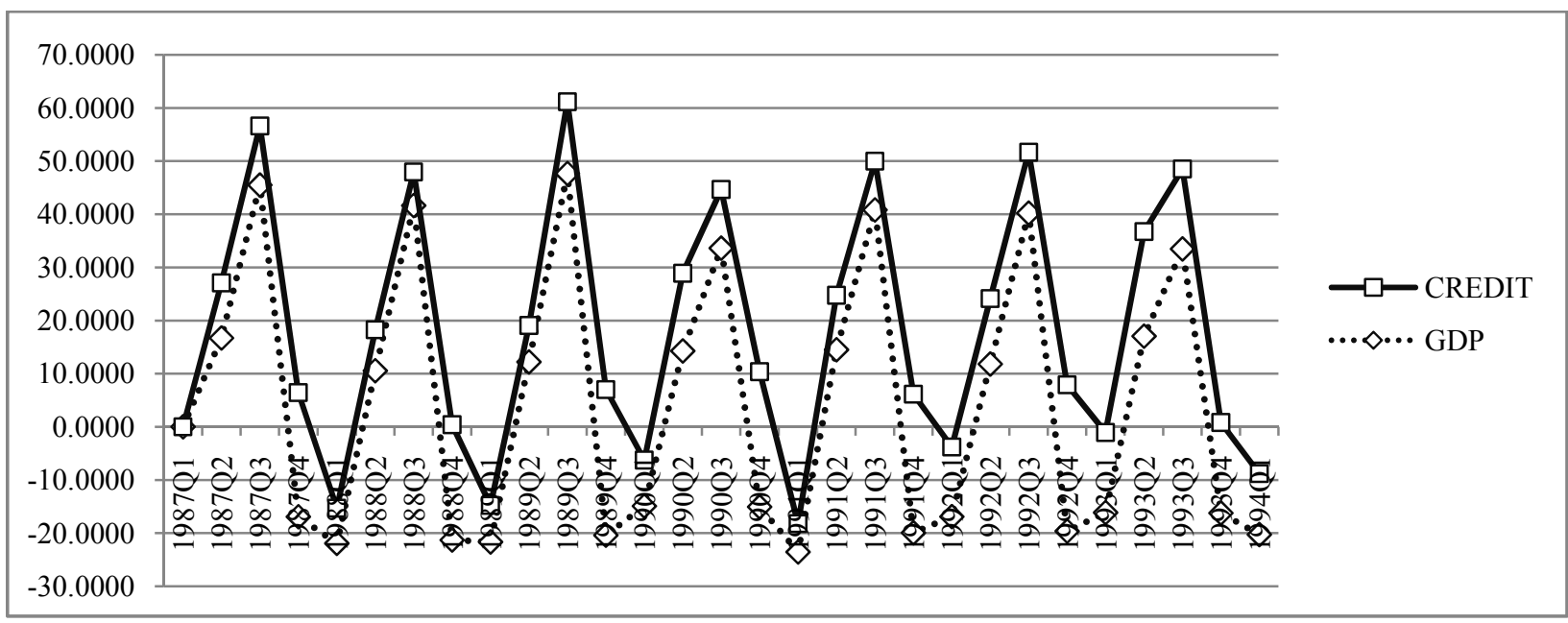

Figure 4. 1987:01-1994:1 period. Source: Central Bank of Republic of Turkey (CBRT). Real GDP growth was calculated based on $(1987=100)$, real credit growth was calculated using real 1987 prices.

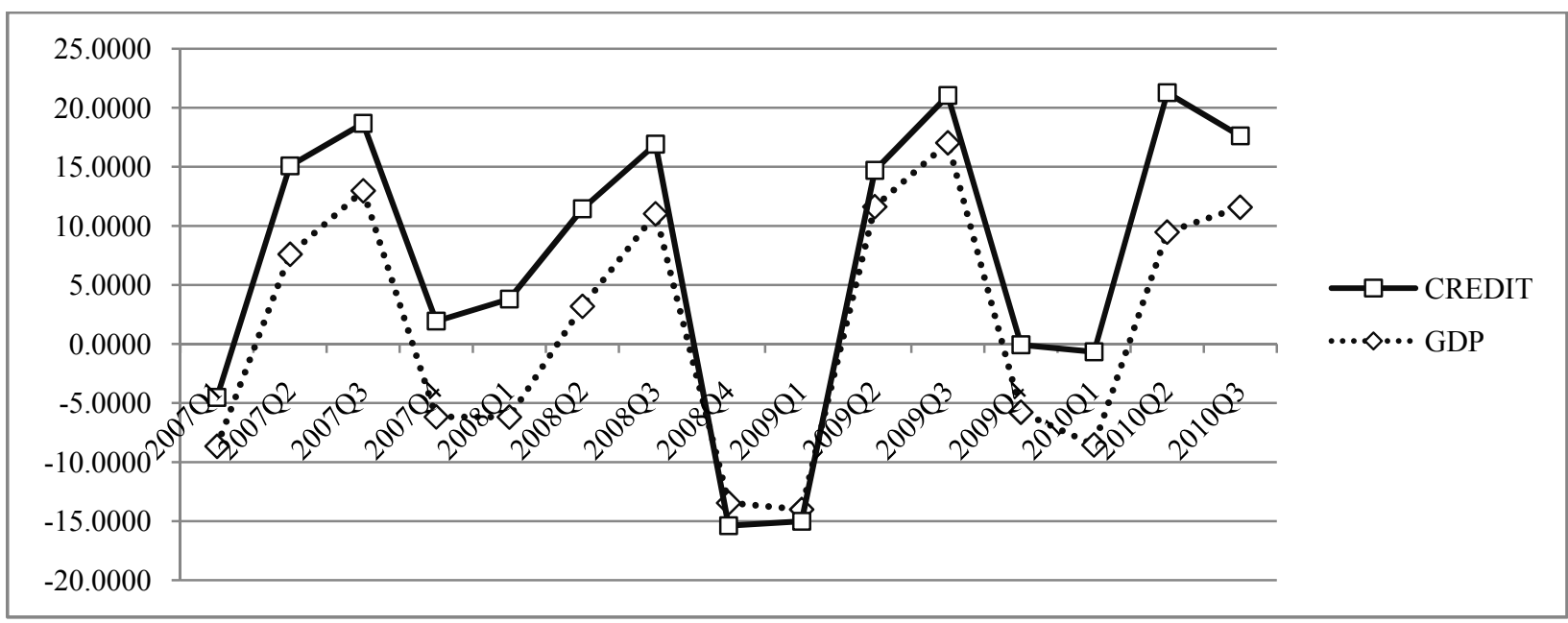

Figure 5. 1994:2-1997:04 period. Source: Central Bank of Republic of Turkey (CBRT). Real GDP growth was calculated based on $(1987=100)$, real credit growth was calculated using real 1987 prices.

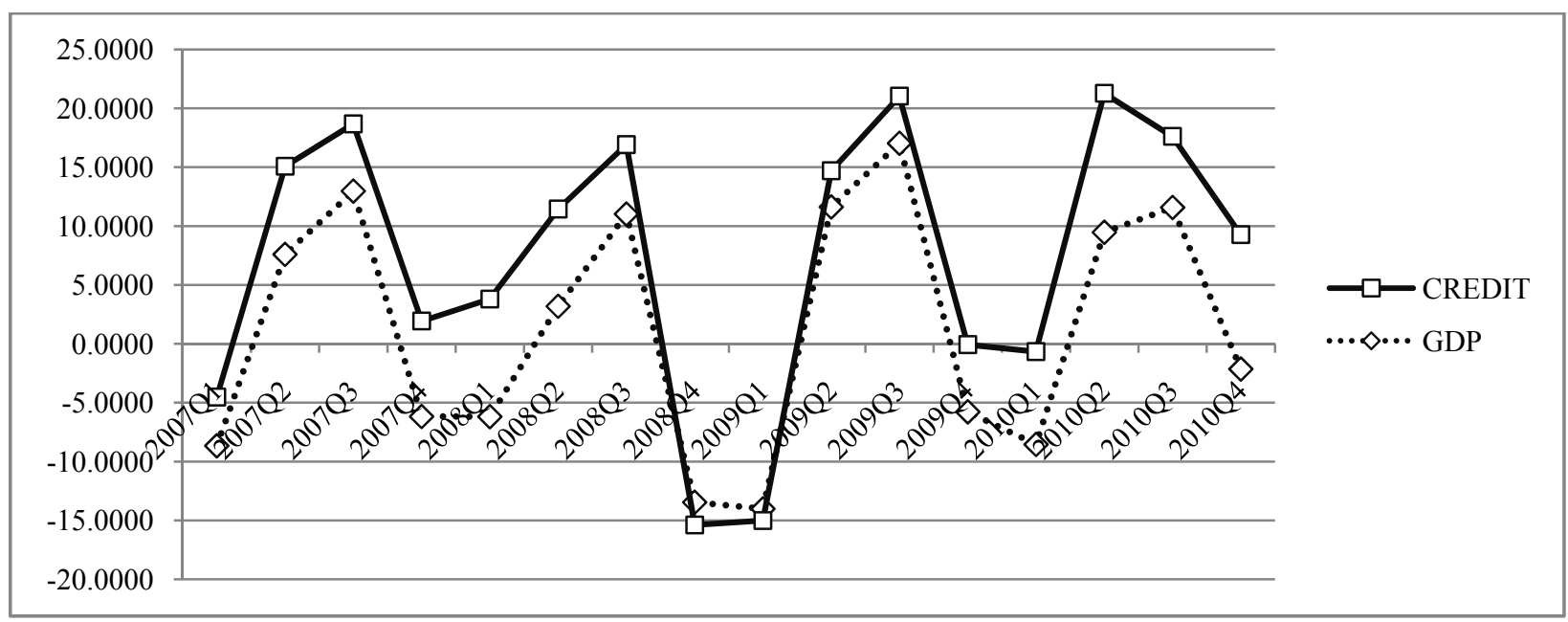

Figure 6. 1998:01-2001:04 period. Source: Central Bank of Republic of Turkey (CBRT). Real GDP growth was calculated based on $(1987=100)$, real credit growth was calculated using real 1987 prices. 


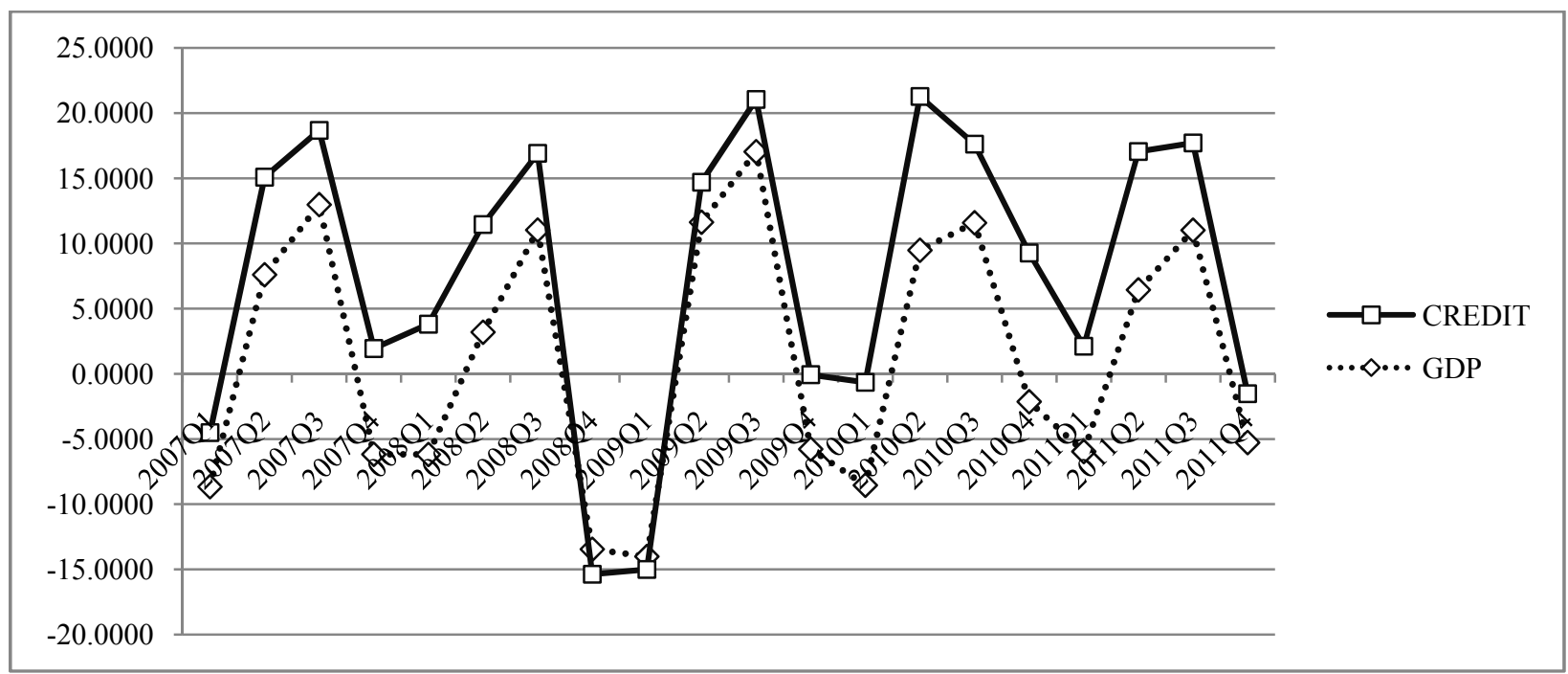

Figure 7. 2002:01-2006:04 period. Source: Central Bank of Republic of Turkey (CBRT). Real GDP growth was calculated based on $(1987=100)$, real credit growth was calculated using real 1987 prices.

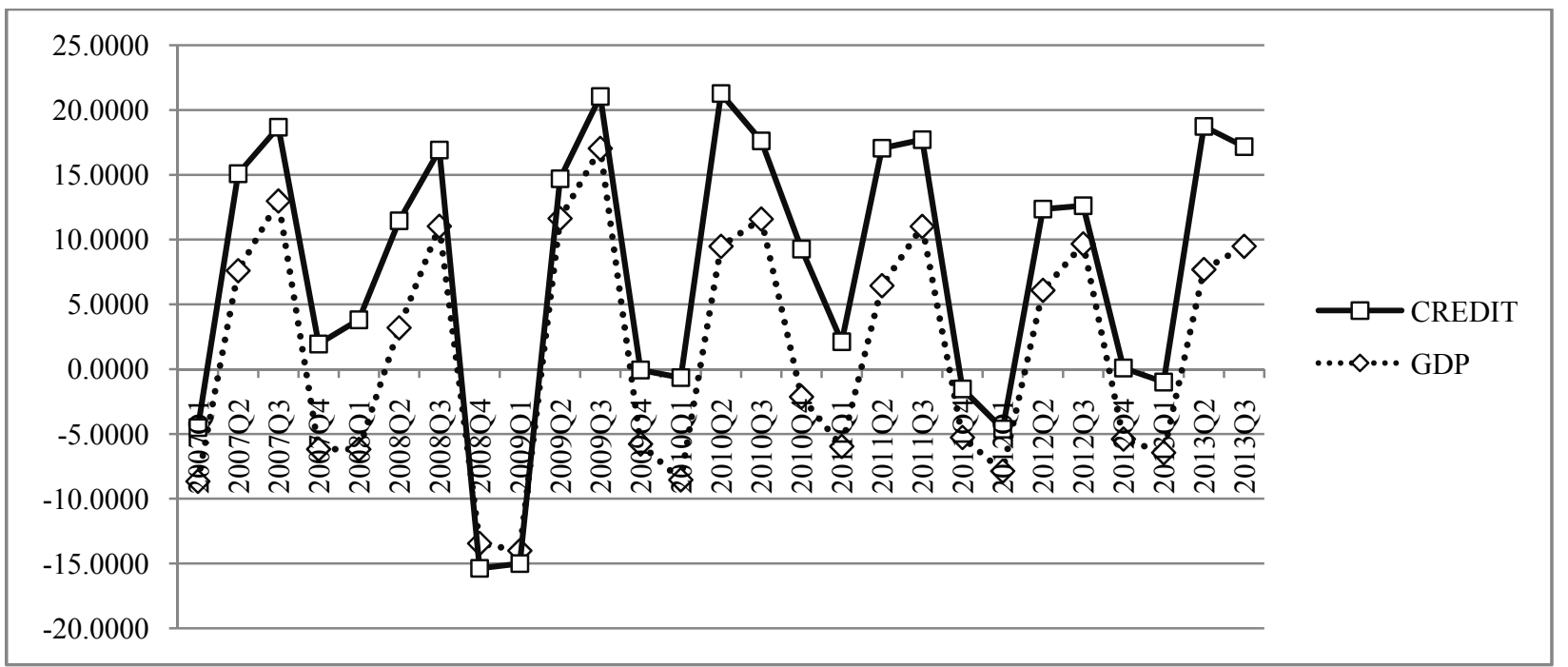

Figure 8. 2007:01-2013:01 period. Source: Central Bank of Republic of Turkey (CBRT). Real GDP growth was calculated based on $(1987=100)$, real credit growth was calculated using real 1987 prices.

Table 1

Real GDP Growth Rate and Real Credit Growth Rate (Descriptive Statistics)

\begin{tabular}{lcccccccc}
\hline 1987:01-2013:03 & RGSYH & RKREDİ & 1987:01-1994:01 & RGSYH & RKREDI & 1994:02-1997:04 & RGSYH & RKREDİ \\
\hline Mean & 2.734621 & 2.353329 & Mean & 4.099060 & 3.176825 & Mean & 4.503452 & 3.176825 \\
Median & 2.331010 & 3.237507 & Median & -2.192596 & 4.239312 & Median & 1.467724 & 4.239312 \\
Maximum & 47.64366 & 20.02420 & Maximum & 47.64366 & 16.86399 & Maximum & 38.52554 & 16.86399 \\
Minimum & -23.56468 & -24.09643 & Minimum & -23.56468 & -24.09643 & Minimum & -16.60961 & -24.09643 \\
Std. Dev. & 17.68940 & 6.967239 & Std. Dev. & 25.55171 & 9.693737 & Std. Dev. & 20.91909 & 9.693737 \\
Skewness & 0.530699 & -0.869235 & Skewness & 0.413997 & -1.337099 & Skewness & 0.270310 & -1.337099 \\
Kurtosis & 2.473067 & 5.105246 & Kurtosis & 1.610154 & 5.392599 & Kurtosis & 1.432077 & 5.392599 \\
Jarque-Bera & 6.201995 & 32.92334 & Jarque-Bera & 3.053454 & 8.047418 & Jarque-Bera & 1.719159 & 8.047418 \\
Probability & 0.045004 & 0.000000 & Probability & 0.217246 & 0.017887 & Probability & 0.423340 & 0.017887 \\
\hline
\end{tabular}


Table 1 continued

\begin{tabular}{lcccccccc}
\hline 1998:01-2001:04 & RGSYH & RKREDİ & 2002:01-2006:04 & RGSYH & RKREDİ & 2007:01-2013:03 & RGSYH & RKREDİ \\
\hline Mean & 1.020088 & -1.911275 & Mean & 2.608997 & 8.437987 & Mean & 1.44604 & 4.234417 \\
Median & -1.52671 & -0.765391 & Median & 0.232916 & 7.882091 & Median & 3.194296 & 4.426821 \\
Maximum & 23.42642 & 6.949795 & Maximum & 21.65655 & 21.89217 & Maximum & 17.04469 & 10.63756 \\
Minimum & -20.2691 & -16.63003 & Minimum & -11.82553 & -6.98707 & Minimum & -14.01542 & -5.005846 \\
Std. Dev. & 16.03153 & 6.3583 & Std. Dev. & 11.9847 & 6.981105 & Std. Dev. & 9.26192 & 3.520592 \\
Skewness & 0.1401 & 0.761285 & Skewness & 0.239469 & -0.09078 & Skewness & -0.058565 & -0.554165 \\
Kurtosis & 1.399653 & 3.200899 & Kurtosis & 1.408518 & 2.960325 & Kurtosis & 1.559287 & 3.358375 \\
Jarque-Bera & 1.759749 & 1.572385 & Jarque-Bera & 6.905493 & 0.086344 & Jarque-Bera & 2.350544 & 1.526431 \\
Probability & 0.414835 & 0.455576 & Probability & 0.031659 & 0.957747 & Probability & 0.308735 & 0.466165 \\
\hline
\end{tabular}

\section{Empirical Results}

A standard vector autoregression (VAR), which recognizes the endogeneity of macroeconomic variables, is written as follows:

$$
y_{t}=A_{0+} A_{1} y_{t-1}+\ldots A_{p, t} y_{t-p}+\varepsilon_{t}
$$

where $y$ is a vector of observable endogenous variables.

The core of our VAR comprises just four variables: log real loan volumes $(c r d)$, log real GDP $(y)$, the general price level (cpi), and log real monetary supply (m2). Also crisis variables are added to the model as dummy variables. These variables are 1994 crisis, 2001 crisis, and 2008 crisis. All variables were transformed from nominal values to real values by using the CPI $(1987=100)$.

The model was estimated with quarterly data for period 1987Q1-2013Q3. All data were taken from the Central Bank of the Turkish Republic Electronic Data Distribution System.

Table 2

Results of the Unit Root Test

\begin{tabular}{lllll}
\hline \multirow{2}{*}{ Variables } & \multicolumn{3}{c}{ (Level) } & (1st Dif.) \\
\cline { 2 - 5 } & Intercept & Intercept and trend & Intercept & Intercept and trend \\
\hline crd & $1.18(1)$ & $-1.24(1)$ & $-7.52(0)$ & $*-7.93(0)^{*}$ \\
$y$ & $-0.45(0)$ & $-3.11(0)$ & $-10.42(0)^{*}$ & $-10.38(0)^{*}$ \\
$m 2$ & $-1.10(3)$ & $-2.24(3)$ & $-13.61(2)^{*}$ & $-13.52(2)^{*}$ \\
\hline
\end{tabular}

Note. *The critical values at a significance level of $1 \%$ in the ADF test, for intercept model and intercept and trend model are -3.49 and -4.05 respectively.

Table 3

Johansen Cointegration Rank Test Results

\begin{tabular}{llll}
\hline Null hypothesis & Eigenvalue & Trace statistic & $5 \%$ critical value \\
\hline $\mathrm{H}_{0}: r=0$ & 0.495 & $165.799^{*}$ & 125.615 \\
$\mathrm{H}_{0}: r \leq 1$ & 0.257 & $96.667^{*}$ & 95.753 \\
$\mathrm{H}_{0}: r \leq 2$ & 0.206 & 66.567 & 69.818 \\
\hline
\end{tabular}

Note. ${ }^{*}$ It shows that the hypothesis is rejected at a level of significance of $5 \%$.

As the first differences of the series are stationary (Table 2), the Johansen cointegration test is used to identify the long-term relationship among variables (Table 3). Criterion LR (Likelihood Ratio) is used to 
determine the lag length of the VAR model and it is essential that the VAR model with the selected lag length has no autocorrelation or heteroscedasticity problems. According to the LR test, the determined lag length is five $(k=5)$.

The long-term equilibrium model containing the variables is as follows:

$$
\begin{aligned}
\Delta c r d= & 4.15 \Delta y+0.14 \Delta m 2-0.11 \Delta c p i-0.03 d m(1994)-0.08 d m(2001)+0.118 d m(2008) \\
& (0.307) \quad(0.072) \quad(0.050) \quad(0.023)
\end{aligned}
$$

This result indicates that there is a long-term equilibrium relationship among all variables. As the Johansen cointegration test proved the presence of a long-term equilibrium relationship between macroeconomic variables and financial variables, one may look at the causality relationship between the variables. An error correction model is used to determine the direction of causality between cointegrated series. The lag length in the error correction model is four $(k=4)$.

Table 4

Vector Error Correction Model

\begin{tabular}{lllll}
\hline Variables & Coefficient & Standard error & $t$-statistic & Probability \\
\hline$\Delta$ CRD (-1) & -0.611110 & 0.2761550 & -2.212921 & $0.0301^{* *}$ \\
$\Delta \mathrm{CRD}(-2)$ & -0.605990 & 0.234330 & -2.586056 & $0.0118^{* *}$ \\
$\Delta \mathrm{CRD}(-3)$ & -0.545775 & 0.190388 & -2.866645 & $0.0055^{* *}$ \\
$\Delta \mathrm{CRD}(-4)$ & -0.372876 & 0.156197 & -2.387218 & $0.0196^{* *}$ \\
$\Delta \mathrm{M} 2$ (-2) & 0.211302 & 0.090423 & 2.336815 & $0.0223^{* *}$ \\
$\Delta \mathrm{DM}(1994)$ & -0.159579 & 0.045476 & --3.50907 & $0.0008^{*}$ \\
$\Delta \mathrm{DM}$ (2008) & -0.129045 & 0.048047 & -2.685802 & $0.0090^{* * *}$ \\
ECM coefficient & -0.611110 & 0.276155 & -2.212921 & $0.0301^{* *}$ \\
R-squared & 0.711472 & & Mean dependent var & 0.001209 \\
Adjusted R-squared & 0.593623 & S.D. dependent var & 0.080746 \\
S.E. of regression & 0.051474 & Akaike info criterion & -2.853876 \\
Sum squared resid & 0.188117 & Schwarz criterion & -2.077108 \\
Log likelihood & 174.1207 & Hannan-Quinn criter. & -2.539418 \\
F-statistic & 6.037132 & Durbin-Watson stat & 2.015703 \\
Prob (F-statistic) & 0.000000 & & & \\
\hline
\end{tabular}

In the estimated error correction model (Table 4), the coefficients of the lagged variables represent the short-term dynamics of the dependent variable. The error correction term in the model is negative and statistically significant. The negative coefficient of the error correction term indicates that the dependent variable meets the short-term adaptation rate for long-term equilibrium.

The coefficient of the money supply variable is positive and significant; the coefficients of dummy variables $(1994,2008)$ are negative and significant. This finding indicates that there is no causal relationship between real GDP and inflation and real loans.

Figure 9 shows the impulse response function of the variables. According to Figure 9, GDP and money supply shocks have a positive impact on real loan volumes. The real loan volumes exhibit a positive response to two quarters and turn negative soon after. The response of loans remains positive after about eight quarters. The response of the loan volumes to inflation rate is negative. 

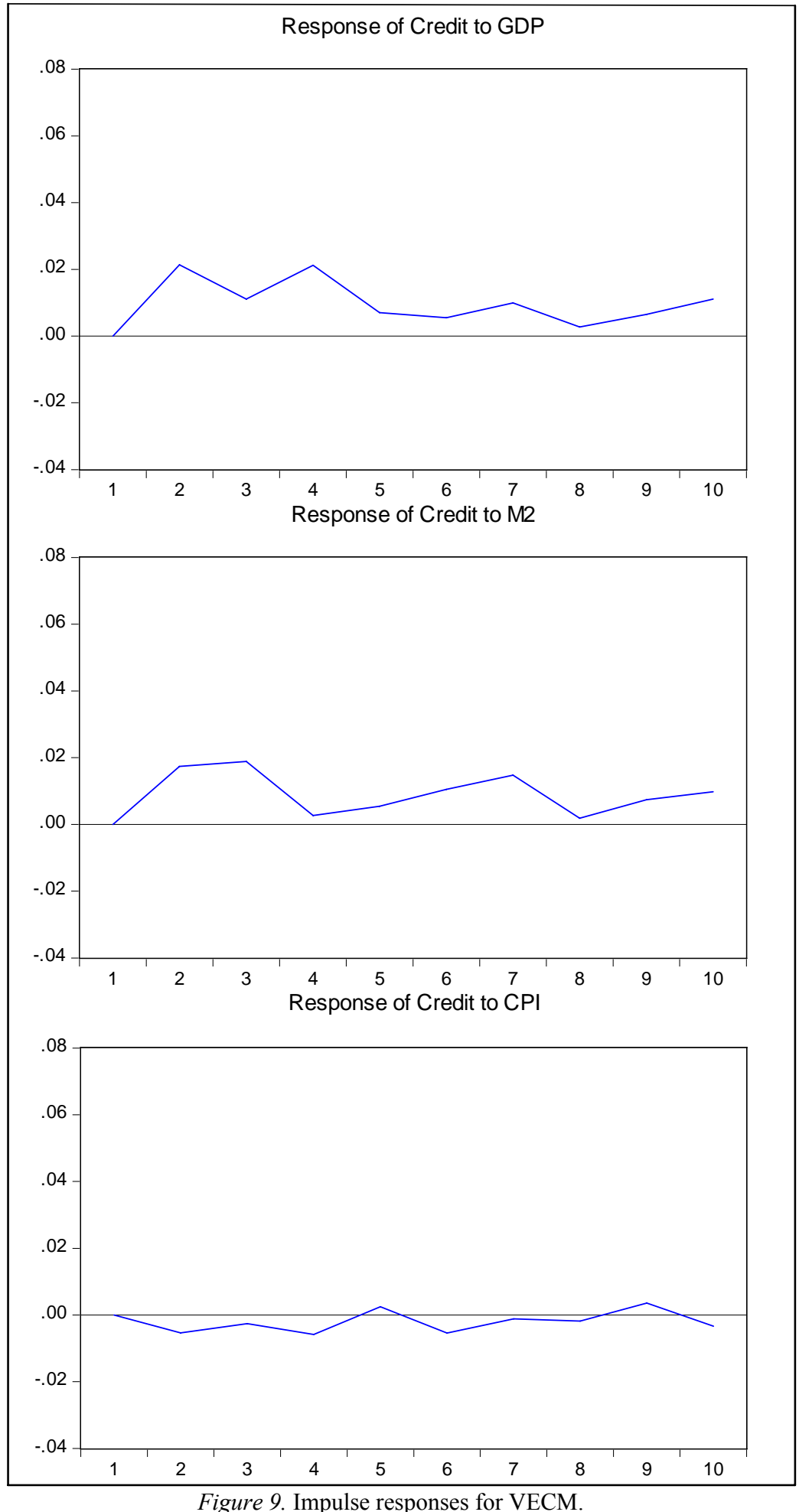

Conclusions

An economic analysis which determined the cyclical component of the real GDP and real bank loans using time series indicated that the real loan growth and real gross domestic product coincide in Turkey. 
The variables used in the econometric model are analyzed for both short- and long-term relationships. The main results of the empirical analysis are as follows. The results of cointegration analysis indicate that there is a single stable long-run equilibrium relationship among real loan volumes, real GDP, real money supply, inflation rate, and crisis variables. Money supply in the 1994 and 2008 crises are found to influence real loan volumes in the short term. The 2001 crisis affects real loan volumes in the long term. Another important finding is that the effect of real GDP on real bank loans is lost in the short term. But, impulse response functions show that the real GDP shocks appear to have a significant effect on credit markets.

\section{References}

Alp, H., Başkaya, Y. S., Kilinç, M., \& Yüksel, C. (2011). Estimating optimal Hodrick-Prescott filter smoothing parameter for Turkey. Anadolu International Conference in Economics II, June 17-17, Turkey: Eskişehir.

Bernanke, B., \& Gertler, M. (1989). Agency costs, net worth and business fluctuations. American Economic Review, 79(1), 14-31. Central Bank of the Republic of Turkey (CBRT). (2012). Retrieved from http://evds.tcmb.gov.tr//

Egert, B., \& Sutherland, D. (2012). The nature of financial and real business cycles: The Great Moderation and banking sector pro-cyclicality. OECD Economics Department Working Papers, No: 938, OECD Publishing.

Gambetti, L., \& Musso, A. (2012). Loan supply shocks and the business cycle. Working Paper Series, No. 1469, 1-18.

Hodrick, R. J., \& Prescott, E. C. (1997). Post-war U.S. business cycles: An empirical investigation. Journal of Money, Credit and Banking, 29(1), 1-16.

Pedersen, T. M. (2001). The Hodrick-Prescott filter, the Slutzky effect, and the distortionary effect of filters. Journal of Economic Dynamics and Control, 25(8), 1081-1101.

Rand, J., \& Tarp, F. (2002). Business cycles in developing countries: Are they different? World Development, 30(12), $2071-2088$. 